\title{
Effect of water chemistry on zooplanktonic and microbial communities across freshwater ecotones in different macrophyte-dominated shallow lakes
}

\author{
Tomasz MIECZAN, ${ }^{*}$ Małgorzata ADAMCZUK, Monika TARKOWSKA-KUKURYK, Dorota NAWROT \\ Department of Hydrobiology, University of Life Sciences, Dobrzańskiego 37, 20-262 Lublin, Poland, tel.: +048 814610061 ext 305 , \\ fax: +048 814610061 \\ *Corresponding author: tomasz.mieczan@up.lublin.pl
}

\begin{abstract}
Complex interactions between zooplankton and microbial food webs are vital to the ecosystem ecology of shallow lakes. However, little is known about how horizontal changes in environmental conditions may influence microbial and metazoan communities in shallow lakes. The specific goals of the study were i) to describe environmental variables responsible for the distribution of bacteria, flagellates, ciliates and crustaceans in an adjacent canal, ecotone and reservoir (littoral-pelagic zone) in two different types of lakes (Ceratophyllum-dominated and Potamogeton-dominated lakes); ii) to determine whether the contact zone waters differ in hydrochemical and biological terms from the waters of the canal and the open water zone; iii) and to evaluate the influence of particular macro-habitats (canal, canal/reservoir, littoral and pelagic zone) on the interactions between components of the planktonic food web. We studied four shallow, eutrophic lakes in Polesie Lubelskie (eastern Poland). The highest diversity and abundance of microorganisms and crustaceans were observed in the canal-reservoir contact zone, while the lowest values were noted in the pelagic zone. Hence, the contact zone in the investigated lakes could fulfil the function of an ecotone, distinguished by a significant increase in biodiversity, abundance, and species specificity of micro- and macroorganisms. Weak relations between food web components were found in the Ceratophyllumdominated lakes, where environmental variables explained the bulk of the total variance in plankton abundance, whereas in the Potamogeton-dominated lakes, where environmental variables had a minor role in the total variance in plankton abundance, strong predator-prey relations were noted. Spatial structure of habitats proved to be another important factor for relationships between food web components, as our study indicated that habitat complexity can reduce negative correlations between food web components. Our study contributes to knowledge of the functioning of eutrophic lakes in the current era of increasing eutrophication caused by climate change and human activity.
\end{abstract}

Key words: Eutrophication; macrophyte; microbial loop; crustaceans.

Received: September 2015. Accepted: December 2015.

\section{INTRODUCTION}

The presence of aquatic submerged vegetation is a very important factor in food webs of shallow lakes. Littoral habitats serve as important sinks for nutrients that enter the lake and are major regulators of nutrient dynamics in lake ecosystems through habitat coupling (Jeppesen et al., 2000; Schindler and Scheuerell, 2002). The littoral zone in shallow lakes comprises a mosaic of vertical and horizontal microhabitats, provided by emergent and submerged macrophytes and open patches. Due to structural and spatial heterogeneity, it maintains a very diverse niche which may allow the coexistence of different life forms (Kairesalo et al., 2000). One of the fascinating roles of macrophytes is their potential to provide refuge for large zooplankton species which, in turn, control the phytoplankton and may also affect the structure and function of the microbial community (Jürgens and Jeppesen, 1997; Kuczyńska-Kippen, 2005). However, little has been known about the microbial communities inhabiting lakes dominated by different types of macrophytes. Understanding the flow of matter and en- ergy through an ecosystem, as described in food web theory, is of paramount importance (Pomeroy 1974; Segovia et al., 2015). Food webs in aquatic ecosystems function via the flow of energy and matter among diverse assemblages of organisms, and are organised into two webs: the 'microbial loop' and the classical grazing chain. They are regulated both by top-predator grazing (top-down control) and nutrient resources (bottom-up control), and the strength of this control is dependent on trophic position and food web length (Pierce and Turner, 1992; Biyu, 2001; Xu et al., 2005). Countless possible relations between distinct levels of microbial and classical food webs in freshwater ecosystems have been described (e.g. Hillbricht-Ilkowska and Węgleńska, 2003; Segovia et al., 2015). While it is well established that metazoan grazing is an important process for the recycling of nutrients and the production of dissolved organic substrates for bacteria, it is also a controlling factor for heterotrophic protist community structure (Fermani et al., 2013; Mieczan and Tarkowska-Kukuryk, 2013). The microbial loop plays an important role in carbon flow and nutrient cycling through microbial components of aquatic 
communities. In addition to bacterial uptake of nonliving organic matter, many direct links exist between algae, bacteria, and other heterotrophic microbes (Azam et al., 1983).

The influence of environmental factors is fairly well documented in the case of seasonal and spatial differences in the abundance and biomass of aquatic animals. However, studies on their relations to food web interactions in ecotonal zones (e.g. littoral zone) of shallow lakes are scarce. Boundaries between water bodies (lakes, ponds or reservoirs) and adjacent terrestrial patches play an important role in the coupling of terrestrial and aquatic ecosystems. Ecotones are transition zones between relatively homogenous areas or patches (di Castri et al., 1988). They are zones in which environmental gradients are steeper and rates of change in ecological patterns and processes are increased relative to the surrounding zones. The canal-reservoir system may thus be perceived as a spatial system of two kinds of ecosystems or patches. Ecotonal zones of these patches are formed by the mixing of reservoir water with river/canal water (Hillbricht-Ilkowska and Węgleńska, 2003). The zone of river inflow to a reservoir functions as a barrier system and filter of incoming organic matter, nutrients and suspended minerals. Studies on the effect of ecotones on freshwater communities have focused on rotifers (EjsmontKarabin, 2003), bacteria and periphyton (Fleituch et al., 2001). However, our knowledge of the distribution and regulating factors of micro- and macroorganisms in transitional zones in shallow lakes is still fragmentary. Because the canal/reservoir zone is recognised as an ecotone (the contact zone between two different ecosystems - water/ water ecotone), it was postulated that it should exhibit significant differences in physical and chemical water parameters from adjacent habitats and be distinguished by high species richness and abundance of bacteria, flagellates, ciliates and crustaceans, including species typical of the zone. The specific goals of the study were to analyse the abundance of microbial and crustacean communities; to describe environmental variables responsible for the distribution of bacteria, flagellates, ciliates and crustaceans in an adjacent canal, ecotone and reservoir (littoral-pelagic zone); to determine whether the contact zone waters differ in hydrochemical and biological terms from the waters of the canal and the open water zone; and to evaluate the influence of particular macro-habitats (canal, canal/reservoir, littoral and pelagic zone) on the interactions between components of the planktonic food web.

\section{METHODS}

\section{Study area}

The study area comprised four shallow (depth 1.5-2.2 $\mathrm{m}$ ), eutrophic and polymictic lakes (Dratów, Krzczeń, Domaszne and Białe Libiszowskie) in the Polesie Lubelskie region of eastern Poland $\left(51^{\circ}\right.$ N, $23^{\circ}$ E) (Fig. 1). Over 70-
$80 \%$ of the catchment area of the lakes is used for agriculture (mainly arable land and meadows). In 1961, these lakes were connected to the Wieprz-Krzna Canal (WKC) (Dawidek et al., 2004). Due to feeding with canal waters, the rate of water exchange in the lakes increased and its quality and trophic condition improved. The hydrotechnological facilities are efficient, carefully maintained and fully functional. The water in the reservoirs is replaced several times in a hydrological year, irrespective of the natural feeding system (Dawidek et al., 2004). The lakes represent two types of macrophyte community. Lakes Białe Libiszowskie and Dratów are classified as Potamogeton-dominated, with total coverage of the bottom ranging from $7 \%$ to $11 \%$; Potamogeton lucens L. dominated in the species structure with five accompanying macrophyte species: Ceratophyllum demersum L., Potamogeton crispus L., Myriophyllum spicatum L. and Stratiotes aloides L. The other two lakes, Krzczeń and Domaszne, represent the Ceratophyllum-dominated type. The total area overgrown by submerged vegetation varied between $28 \%$ and $39 \%$; C. demersum dominated in the species structure, with the accompanying species M. spicatum, P. crispus and Potamogeton pectinatus L.

\section{Sampling and identification}

Microbial communities (bacteria, heterotrophic flagellates and ciliates) and crustaceans (cladocerans and copepods) were examined in a horizontal transect including the following: 1, the Wieprz-Krzna Canal (WKC); 2, the canal/reservoir contact zone (WKC/R); 3 , the littoral zone (L); and 4, the pelagic zone (P). The samples were taken in April, July and October 2012-2013. In each of the study seasons three samples were collected from each habitat, so that 72 (36 in 2012 and 36 in 2013) samples were collected in spring, summer and autumn in these lakes. Samples were collected with a 5-litre Bernatowicz sampler at all sites.

Abundances of bacteria were determined using DAPI - 4'6-diamino-2-phenylindole (Porter and Feig, 1980). Water samples of $10 \mathrm{~mL}$ were preserved in formaldehyde to a final concentration of $2 \%$ and kept in darkness at $4{ }^{\circ} \mathrm{C}$. Preparations were made within $24 \mathrm{~h}$ after sampling. Four slides were made from each sample, with 2-mL subsamples filtered on $0.2-\mu \mathrm{m}$-pore-size polycarbonate filters stained with irgalan black. Epifluorescence microscopy (Nikon, Eclipse) was used to determine total bacterial cell numbers (at 1250× magnification, epifluorescence illuminator HB2-RFL, a mercury lamp HB0-100W, neofluor objective lens 100/1.25). Bacteria were chosen from 5-10 randomly selected fields of each microscope slide and 250-300 cell per slide were counted.

Abundances of heterotrophic flagellates (HF) were determined with primuline solution (Caron, 1983). Water samples of $10 \mathrm{~mL}$ were collected into dark sterilised bottles. The samples were preserved in formalin to a final 
concentration of $2 \%$ and kept in darkness at $4{ }^{\circ} \mathrm{C}$. Four preparations were made from each sample. Sub-samples were condensed on $0.8-\mu \mathrm{m}$-pore-size black Nucleopore filters and enumerated by epifluorescence microscopy (at $1250 \times$ magnification).

Abundances of ciliates and their community composition were determined using the Utermöhl method, at $600 \times$ magnification (Utermöhl, 1958). Ciliate samples (3 samples; $500 \mathrm{~mL}$ each) were sedimented for $24 \mathrm{~h}$ in a cylinder stoppered with Parafilm and then the upper volume of $400 \mathrm{~mL}$ was gently removed. To determine density and biomass, three samples were preserved with Lugol's solution. Additionally, live samples were observed for taxonomic identification. Because ciliates are highly perishable and their type of motility is a species-specific feature, species determination and measurements were carried out on live material immediately upon return to the laboratory and after silver impregnation (Augustin et al., 1984). Morphological identification was mainly based on works by Foissner and Berger (1996), Foissner et al., (1999). Crustaceans (Cladocera and Copepoda) were collected with a 5-L sampler. Double samples were collected and pooled to reduce heterogeneity in crustacean distribution and sampling variability. Samples were sieved through in a 40- $\mu \mathrm{m}$ mesh net and fixed with formalin-glycerine solution. In the laboratory, the classification and counts of crustaceans were made with a Sedgewick-Rafter cell (at $100 \times$ magnification); abundance was expressed as the number of individuals per $\mathrm{L}$.

\section{Physical and chemical parameters}

Simultaneously to the biological examinations, a number of physical and chemical analyses were conducted. Visibility was estimated with a Secchi disc (SD). Temperature, conductivity, $\mathrm{pH}$ and dissolved oxygen (DO) were determined in situ with a multiparametric Probe (Hanna Instruments). Total suspended solids (TSS) were determined using a PASTEL UV spectrophotometer, and the remaining factors (total phosphorus), $\mathrm{P}-\mathrm{PO}_{4}{ }^{3-}, \mathrm{N}^{-} \mathrm{NH}_{4}$ and $\mathrm{N}-\mathrm{NO}_{3}$ ) were analysed in the laboratory (Golterman, 1969). Total phosphorus $\left(P_{\text {tot }}\right)$ and ortophosphates were measured using a spectrophotometer UV-1610 Schimadzu (with molybdate method after mineralization with a mixture of $\mathrm{HNO}_{3}$ and $\mathrm{H}_{2} \mathrm{SO}_{4}$ ), nitrate (with sodium salicylate method) and N-NH$H_{4}$ by the Kjeldahl's method. Chlorophyll $a$ concentration was determined by spectrophoto-

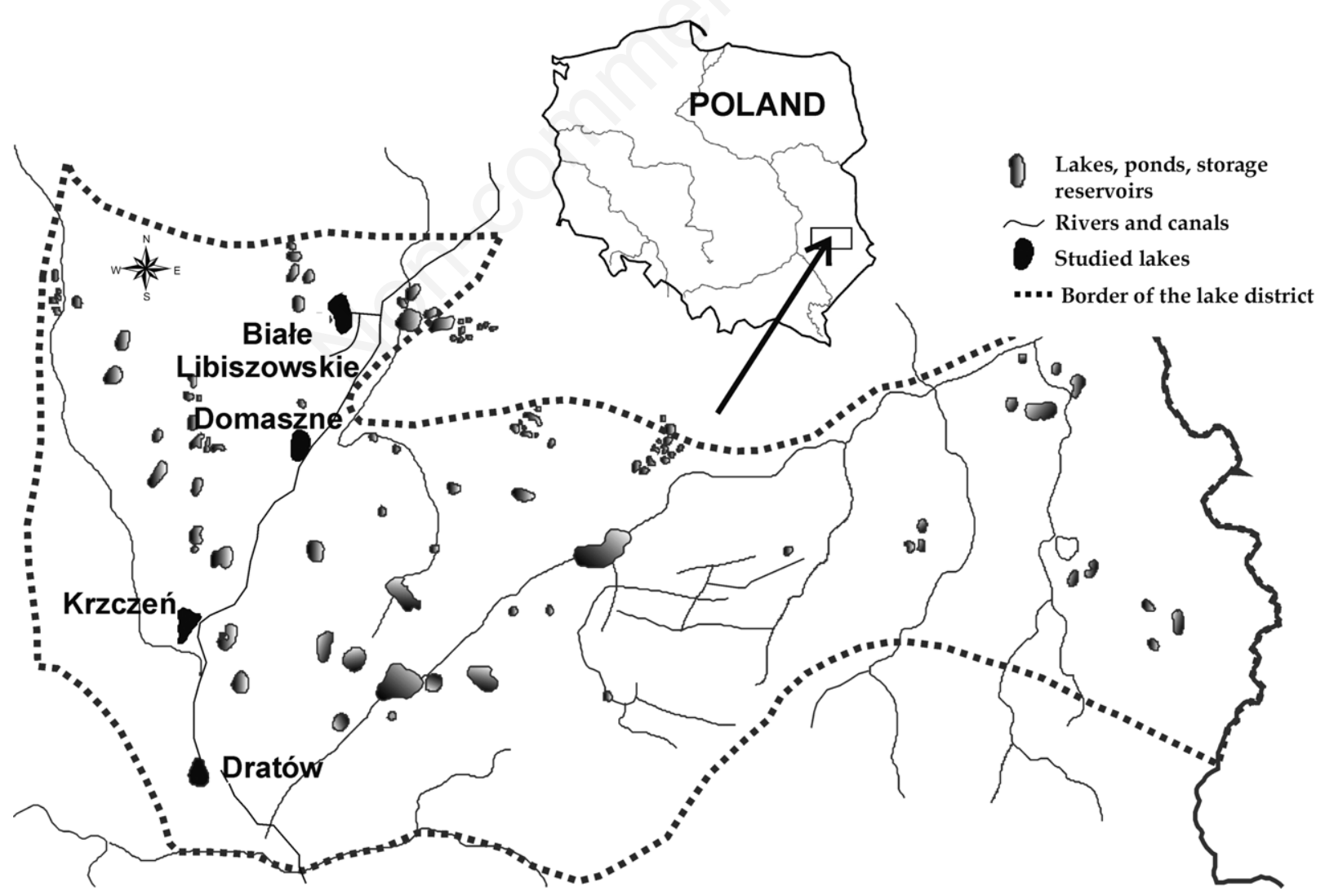

Fig. 1. Location of the studied lakes and sampling points. 
metric analysis of acetone extracts of algae retained on Whatman GF/F filters $(0.7 \mu \mathrm{m}, 2.5 \mathrm{~cm}$ diameter $)$ according to Golterman (1969).

\section{Statistical analyses}

Differences in the physical and chemical parameters and in abundance of microbial communities and crustaceans in the different sites were tested using ANOVA. When significant differences were observed, the post-hoc sequential Bonferroni test was performed (Quinn and Keough, 2002). The initial critical probability value was set at $\mathrm{P}<0.05 / \mathrm{n}$, where $\mathrm{n}=$ number of samples collected in lake type $(n=36)$. Ordination techniques were used to describe the relationships between groups of the planktonic food web and environmental variables. The length of the gradient indicated by Detrended Correspondence Analysis of the communities was $<2 \mathrm{SD}$, which suggests that redundancy analysis (RDA) was an appropriate method (Ter Braak, 1988-1992). RDA analysis was performed in order to specify the effect of environmental variables on planktonic communities. Moreover, RDA was used to to recognize the importance of environmental conditions on the distribution of ciliate, cladoceran and copepod species along the horizontal gradient (WKC, WKC/R, L, P). The Monte Carlo permutation test (999 permutations) was applied to determine the significance $(\mathrm{P}<0.05)$ of variables. All analyses were performed using CANOCO 4.5 for Windows.

Spearman rank correlation coefficients were calculated to determine the relationships between components of the pelagic food web with respect to the site studied, using Statistica 10.0 Software.

\section{RESULTS}

\section{Abiotic variables}

Physical and chemical water parameters varied between sites and lake types (Tab. 1). In Potamogeton-dominated lakes significant differences between the sites were found for conductivity (ANOVA, $\mathrm{F}=11.15, \mathrm{P}<0.001$ ), dissolved oxygen (ANOVA, $\mathrm{F}=16.15, \mathrm{P}<0.001$ ), $\mathrm{N}^{-\mathrm{NO}_{3}}$ (ANOVA, $\quad \mathrm{F}=14.34, \quad \mathrm{P}=0.0012), \quad \mathrm{P}-\mathrm{PO}_{4} \quad$ (ANOVA, $\mathrm{F}=11.88, \quad \mathrm{P}=0.0013$ ) and chlorophyll $a$ (ANOVA, $\mathrm{F}=15.73, \mathrm{P}=0.0011$ ). In Ceratophyllum-dominated lakes, four environmental parameters changed significantly along the horizontal gradient: conductivity (ANOVA, $\mathrm{F}=24.41, \mathrm{P}<0.001$ ), $\mathrm{N}^{-N_{4}}$ (ANOVA, $\mathrm{F}=7.78, \mathrm{P}=0.001$ ), $\mathrm{N}-\mathrm{NO}_{3}$ (ANOVA, $\mathrm{F}=69.57, \quad \mathrm{P}<0.001$ ) and $\mathrm{P}_{-} \mathrm{PO}_{4}$ (ANOVA, $\mathrm{F}=83.25, \mathrm{P}<0.001$ ).

\section{Bacteria, flagellates, ciliates and crustaceans}

In Potamogeton-dominated lakes the highest mean bacterial numbers were noted in the littoral zone (L) $\left(18 \pm 2 \times 10^{6}\right.$ cells $\left.\mathrm{mL}^{-1}\right)$ and the highest mean flagellate

Tab. 1. Mean values $( \pm \mathrm{SD})$ of physical and chemical water parameters at studied sites.

\begin{tabular}{|c|c|c|c|c|c|c|c|c|}
\hline & \multicolumn{4}{|c|}{ Potamogeton-dominated lakes } & \multicolumn{4}{|c|}{ Ceratophyllum-dominated lakes } \\
\hline & WKC & WKC/R & $\mathbf{L}$ & $\mathbf{P}$ & WKC & WKC/R & $\mathbf{L}$ & $\mathbf{P}$ \\
\hline Temperature $\left({ }^{\circ} \mathrm{C}\right)$ & $\begin{array}{l}15.1 \\
\pm 4.1\end{array}$ & $\begin{array}{l}15.4 \\
\pm 4.4\end{array}$ & $\begin{array}{l}15.7 \\
\pm 4.8\end{array}$ & $\begin{array}{l}15.6 \\
\pm 4.7\end{array}$ & $\begin{array}{l}15.1 \\
\pm 4.3\end{array}$ & $\begin{array}{l}15.6 \\
\pm 5.4\end{array}$ & $\begin{array}{l}15.9 \\
\pm 5.3\end{array}$ & $\begin{array}{l}15.7 \\
\pm 5.2\end{array}$ \\
\hline $\mathrm{pH}$ & $\begin{array}{r}7.7 \\
\pm 0.3\end{array}$ & $\begin{array}{r}7.8 \\
\pm 0.5\end{array}$ & $\begin{array}{r}8.1 \\
\pm 0.4\end{array}$ & $\begin{array}{r}8.4 \\
\pm 0.3\end{array}$ & $\begin{array}{r}8.1 \\
\pm 0.4\end{array}$ & $\begin{array}{r}7.8 \\
\pm 0.5\end{array}$ & $\begin{array}{r}8.3 \\
\pm 0.4\end{array}$ & $\begin{array}{r}8.2 \\
\pm 0.4\end{array}$ \\
\hline Conductivity $\left(\mu \mathrm{S} \mathrm{cm}^{-1}\right)$ & $\begin{array}{r}385 \\
\pm 132\end{array}$ & $\begin{array}{r}260 \\
\pm 112\end{array}$ & $\begin{array}{r}258 \\
\pm 102\end{array}$ & $\begin{array}{r}251 \\
\pm 103\end{array}$ & $\begin{array}{r}415 \\
\pm 115\end{array}$ & $\begin{array}{r}295 \\
\pm 105\end{array}$ & $\begin{array}{r}239 \\
\pm 103\end{array}$ & $\begin{array}{r}234 \\
\pm 113\end{array}$ \\
\hline Dissolved oxygen $\left(\mathrm{mg} \mathrm{L}^{-1}\right)$ & $\begin{array}{r}8.44 \\
\pm 1.71 \\
\end{array}$ & $\begin{array}{l}9.36 \\
\pm 2.0\end{array}$ & $\begin{array}{r}9.59 \\
\pm 1.46 \\
\end{array}$ & $\begin{array}{l}11.54 \\
\pm 1.85\end{array}$ & $\begin{array}{l}10.20 \\
\pm 2.31 \\
\end{array}$ & $\begin{array}{r}8.31 \\
\pm 1.76 \\
\end{array}$ & $\begin{array}{l}19.48 \\
\pm 1.96 \\
\end{array}$ & $\begin{array}{l}11.27 \\
\pm 1.66\end{array}$ \\
\hline $\mathrm{N}-\mathrm{NH}_{4}\left(\mathrm{mg} \mathrm{L}^{-1}\right)$ & $\begin{array}{r}0.242 \\
\pm 0.072\end{array}$ & $\begin{array}{r}0.143 \\
\pm 0.047\end{array}$ & $\begin{array}{r}0.139 \\
\pm 0.040\end{array}$ & $\begin{array}{r}0.127 \\
\pm 0.058\end{array}$ & $\begin{array}{r}0.116 \\
\pm 0.277\end{array}$ & $\begin{array}{r}0.117 \\
\pm 0.054\end{array}$ & $\begin{array}{r}0.115 \\
\pm 0.063\end{array}$ & $\begin{array}{r}0.097 \\
\pm 0.061\end{array}$ \\
\hline $\mathrm{N}-\mathrm{NO}_{3}\left(\mathrm{mg} \mathrm{L}^{-1}\right)$ & $\begin{array}{r}0.474 \\
\pm 0.514\end{array}$ & $\begin{array}{r}0.139 \\
\pm 0.053\end{array}$ & $\begin{array}{r}0.127 \\
\pm 0.071 \\
\end{array}$ & $\begin{array}{r}0.128 \\
\pm 0.101 \\
\end{array}$ & $\begin{array}{r}0.610 \\
\pm 0.395 \\
\end{array}$ & $\begin{array}{r}0.184 \\
\pm 0.055\end{array}$ & $\begin{array}{r}0.136 \\
\pm 0.077 \\
\end{array}$ & $\begin{array}{r}0.172 \\
\pm 0.067\end{array}$ \\
\hline $\mathrm{P}-\mathrm{PO}_{4}\left(\mathrm{mg} \mathrm{L}^{-1}\right)$ & $\begin{array}{r}0.093 \\
\pm 0.031\end{array}$ & $\begin{array}{r}0.029 \\
\pm 0.034\end{array}$ & $\begin{array}{r}0.040 \\
\pm 0.043\end{array}$ & $\begin{array}{r}0.033 \\
\pm 0.025\end{array}$ & $\begin{array}{r}0.114 \\
\pm 0.055\end{array}$ & $\begin{array}{r}0.055 \\
\pm 0.028\end{array}$ & $\begin{array}{r}0.029 \\
\pm 0.017\end{array}$ & $\begin{array}{r}0.038 \\
\pm 0.027\end{array}$ \\
\hline$P$ tot $\left(\mathrm{mg} \mathrm{L}^{-1}\right)$ & $\begin{array}{r}0.206 \\
\pm 0.088\end{array}$ & $\begin{array}{r}0.195 \\
\pm 0.075\end{array}$ & $\begin{array}{r}0.200 \\
\pm 0.110\end{array}$ & $\begin{array}{r}0.203 \\
\pm 0.066\end{array}$ & $\begin{array}{r}0.204 \\
\pm 0.160\end{array}$ & $\begin{array}{r}0.184 \\
\pm 0.083\end{array}$ & $\begin{array}{r}0.191 \\
\pm 0.140\end{array}$ & $\begin{array}{r}0.226 \\
\pm 0.130\end{array}$ \\
\hline TOC $\left(\mathrm{mg} \mathrm{L}^{-1}\right)$ & $\begin{array}{r}6.2 \\
\pm 1.6\end{array}$ & $\begin{array}{r}6.0 \\
\pm 0.7\end{array}$ & $\begin{array}{r}6.1 \\
\pm 0.9\end{array}$ & $\begin{array}{r}6.4 \\
\pm 1.1\end{array}$ & $\begin{array}{r}5.9 \\
\pm 0.9\end{array}$ & $\begin{array}{r}5.5 \\
\pm 1.2\end{array}$ & $\begin{array}{r}5.0 \\
\pm 0.7\end{array}$ & $\begin{array}{r}4.9 \\
\pm 1.3\end{array}$ \\
\hline Total suspension $\left(\mathrm{mg} \mathrm{L}^{-1}\right)$ & $\begin{array}{r}14.76 \\
\pm 10.70 \\
\end{array}$ & $\begin{array}{r}25.57 \\
\pm 15.53\end{array}$ & $\begin{array}{r}23.20 \\
\pm 17.60 \\
\end{array}$ & $\begin{array}{r}28.56 \\
\pm 19.55 \\
\end{array}$ & $\begin{array}{r}16.98 \\
\pm 16.18 \\
\end{array}$ & $\begin{array}{l}19.13 \\
\pm 6.00\end{array}$ & $\begin{array}{l}27.24 \\
\pm 6.30\end{array}$ & $\begin{array}{l}24.82 \\
\pm 9.77\end{array}$ \\
\hline Chlorophyll- $a\left(\mu \mathrm{g} \mathrm{L}^{-1}\right)$ & $\begin{array}{r}31.08 \\
\pm 27.26\end{array}$ & $\begin{array}{r}63.58 \\
\pm 26.01\end{array}$ & $\begin{array}{r}57.99 \\
\pm 34.20\end{array}$ & $\begin{array}{r}65.84 \\
\pm 41.08\end{array}$ & $\begin{array}{r}41.41 \\
\pm 21.27\end{array}$ & $\begin{array}{r}87.56 \\
\pm 19.01\end{array}$ & $\begin{array}{r}131.73 \\
\pm 7.88\end{array}$ & $\begin{array}{r}91.36 \\
\pm 11.46\end{array}$ \\
\hline
\end{tabular}

WKC, Wieprz-Krzna Canal; WKC/R, contact zone; L, littoral; P, pelagic zone. 
numbers in $\mathrm{WKC} / \mathrm{R}\left(2 \pm 1 \times 10^{3}\right.$ cells $\left.\mathrm{mL}^{-1}\right)$, while the lowest densities of both groups occurred in WKC $\left(6 \pm 2 \times 10^{6}\right.$ cells $\mathrm{mL}^{-1}$ and $1 \pm 0.2 \times 10^{3}$ cells $\mathrm{mL}^{-1}$, respectively) (Tab. 2). Species richness and density of ciliates and crustaceans showed horizontal variability. The highest taxa numbers for ciliates and copepods occurred in $\mathrm{L}$ and $\mathrm{WKC} / \mathrm{R}$ (20 and 11 taxa, respectively), and for cladocerans in the pelagic zone (P) (25 taxa). The site showed the significant influence on the densities of bacteria (ANOVA, $\mathrm{F}=2.12, \mathrm{P}=0.0011$ ), flagellates (ANOVA, $\mathrm{F}=2.61, \quad \mathrm{P}<0.001$ ) and ciliates (ANOVA, $\mathrm{F}=3.07$, $\mathrm{P}<0.001$ ). The dominance structure of ciliate communities showed no significant differences between sites. The highest abundances were attained by Cinetochilum margaritaceum (WKC, WKC/R, L), Askenasia sp. (WKC, L) and Strombidium viride (WKC/R, P). No horizontal differences were noted in the dominance structure of crustaceans. Bosmina longirostris and Thermocyclops crassus dominated in all of the sites. In Ceratophyllum-dominated lakes, densities of bacteria and flagellates showed a similar pattern to that observed in the Potamogeton-dominated lakes (Tab. 2). Density of ciliates and crustaceans exhibited horizontal variability (Tab. 2). The highest species richness of ciliate, cladoceran and copepod taxa occurred in the littoral zone (L) (24, 21 and 12 taxa, respectively). As in the Potamogeton-dominated lakes, densities of bacteria (ANOVA, $\mathrm{F}=2.87, \mathrm{P}=0.0004$ ), ciliates (ANOVA, $\mathrm{F}=4.56, \mathrm{P}<0.001$ ) and flagellates (ANOVA, $\mathrm{F}=1.06, \mathrm{P}=0.0012$ ) were shown to be significantly affected by the site. The dominance structure of ciliate communities did not differ significantly between the sites. The highest abundances in all sites were attained by C. mar- garitaceum, with accompanying taxa dependent on the site: Askenasia sp. (WKC), Coleps hirtus (WKC/R, L, P) and $S$. viride (WKC/R, L, P). Horizontal differences were not noted in the dominance structure of cladocerans. $B$. longirostris dominated in all of the sites, accompanied by significant share of Alonella nana (WKC/R), Chydorus sphaericus (WKC/R, L, P) and Daphnia cucullata (L) and copepods - Mesocyclops leuckartii (in all sites).

\section{Ordination analyses}

In the Potamogeton-dominated lakes all the variables together explained $53.1 \%$ of the total variance. Variables that significantly $(\mathrm{P}<0.05$, Monte Carlo permutation test) explained the variance in the abundance of planktonic communities were temperature $(\lambda=0.04 ; \mathrm{F}=2.59 ; \mathrm{P}=0.048)$, visibility (Secchi depth) $(\lambda=0.06 ; \quad \mathrm{F}=3.99 ; \quad \mathrm{P}=0.012)$, conductivity $(\lambda=0.10 ; \mathrm{F}=6.24 ; \mathrm{P}=0.002)$ and $\mathrm{N}-\mathrm{NO}_{3}$ $(\lambda=0.19 ; \mathrm{F}=11.04 ; \mathrm{P}=0.002)$. On the RDA triplot, axis 1 appears to separate individual components of the planktonic food web; bacteria, ciliates and cladocerans are separated from flagellates and copepods (Fig. 2A). Axis 2 separates samples collected in WKC from other sites (WKC/R, L and $\mathrm{P})$. Samples collected in the littoral and pelagic zones may correspond with abundances of bacteria, ciliates and cladocerans, while the presence of flagellates corresponds with samples collected in $\mathrm{WKC} / \mathrm{R}$. However, RDAs performed separately for planktonic groups (ciliates, cladocerans and copepods) showed high variability in species-environment relations. The RDA for spatial distribution of ciliates showed that all the environmental variables together explained $73.7 \%$ of the total variance. The Monte Carlo permutation test showed the significance of temperature

Tab. 2. Mean densities ( \pm SD) of the years 2012-2013 of components of planktonic food web in studied lakes.

\begin{tabular}{|c|c|c|c|c|c|c|c|c|}
\hline \multicolumn{9}{|c|}{ Potamogeton-dominated lakes } \\
\hline & \multicolumn{4}{|c|}{ Biale Libiszowskie } & \multicolumn{4}{|c|}{ Dratów } \\
\hline & WKC & WKC/R & L & $\mathbf{P}$ & WKC & WKC/R & $\mathrm{L}$ & $\mathbf{P}$ \\
\hline Bacteria (cells mL $\mathrm{mL}^{-1}$ ) & $4 \pm 2 \times 10^{6}$ & $19 \pm 1.5 \times 10^{6}$ & $20 \pm 3 \times 10^{6}$ & $8 \pm 1 \times 10^{6}$ & $8 \pm 2 \times 10^{6}$ & $15 \pm 1 \times 10^{6}$ & $16 \pm 3 \times 10^{6}$ & $6 \pm 2 \times 10^{6}$ \\
\hline Flagellates (cells $\mathrm{mL}^{-1}$ ) & $1 \pm 0.3 \times 10^{3}$ & $2.5 \pm 0.8 \times 10^{3}$ & $1.8 \pm 0.8 \times 10^{3}$ & $1.5 \pm 0.4 \times 10^{3}$ & $1 \pm 0.3 \times 10^{3}$ & $1.5 \pm 0.6 \times 10^{3}$ & $1.4 \pm 1.2 \times 10^{3}$ & $1.3 \pm 1 \times 10^{3}$ \\
\hline Ciliates (ind. $\mathrm{L}^{-1}$ ) & $169 \pm 19$ & $298 \pm 27$ & $145 \pm 11$ & $141 \pm 16$ & $120 \pm 18$ & $199 \pm 17$ & $247 \pm 23$ & $203 \pm 32$ \\
\hline Cladocerans (ind. $\mathrm{L}^{-1}$ ) & $233 \pm 13$ & $161 \pm 26$ & $3004 \pm 123$ & $29608 \pm 324$ & $803 \pm 27$ & $337 \pm 22$ & $10790 \pm 165$ & $6364 \pm 152$ \\
\hline \multirow[t]{4}{*}{ Copepods (ind. L $\mathrm{L}^{-1}$ ) } & $258 \pm 13$ & $2421 \pm 39$ & $1526 \pm 31$ & $2728 \pm 31$ & $464 \pm 22$ & $3051 \pm 59$ & $2057 \pm 42$ & $3145 \pm 58$ \\
\hline & \multicolumn{8}{|c|}{ Ceratophyllum-dominated lakes } \\
\hline & \multicolumn{4}{|c|}{ Domaszze } & \multicolumn{4}{|c|}{ Krzczeń } \\
\hline & WKC & WKC/R & L & $P$ & WKC & WKC/R & $\mathrm{L}$ & $P$ \\
\hline Bacteria (cells mL $\mathrm{mL}^{-1}$ ) & $11 \pm 1 \times 10^{6}$ & $12 \pm 2 \times 10^{6}$ & $14 \pm 1 \times 10^{6}$ & $14 \pm 1 \times 10^{6}$ & $9 \pm 1 \times 10^{6}$ & $10 \pm 1.5 \times 10^{6}$ & $12 \pm 3 \times 10^{6}$ & $10 \pm 3 \times 10^{6}$ \\
\hline Flagellates (cells mL $\mathrm{mL}^{-1}$ ) & $3 \pm 1.1 \times 10^{3}$ & $3.2 \pm 0.7 \times 10^{3}$ & $1.3 \pm 0.6 \times 10^{3}$ & $1.4 \pm 1.1 \times 10^{3}$ & $1 \pm 0.8 \times 10^{3}$ & $2.8 \pm 0.8 \times 10^{3}$ & $0.9 \pm 1 \times 10^{3}$ & $1 \pm 0.8 \times 10^{3}$ \\
\hline Ciliates (ind. $\mathrm{L}^{-1}$ ) & $115 \pm 29$ & $264 \pm 31$ & $213 \pm 14$ & $147 \pm 21$ & $166 \pm 32$ & $329 \pm 24$ & $306 \pm 29$ & $296 \pm 11$ \\
\hline Cladocerans (ind. $\mathrm{L}^{-1}$ ) & $236 \pm 13$ & $581 \pm 19$ & $2072 \pm 89$ & $1314 \pm 27$ & $59 \pm 12$ & $416 \pm 32$ & $976 \pm 52$ & $2235 \pm 49$ \\
\hline Copepods (ind. L $\mathrm{L}^{-1}$ ) & $216 \pm 19$ & $2358 \pm 39$ & $1698 \pm 42$ & $3165 \pm 61$ & $131 \pm 23$ & $1374 \pm 49$ & $1844 \pm 47$ & $1174 \pm 54$ \\
\hline
\end{tabular}

WKC, Wieprz-Krzna Canal; WKC/R, contact zone; L, littoral; P, pelagic zone. 
$(\lambda=0.04, \mathrm{~F}=2.08, \mathrm{P}=0.022), \mathrm{pH}(\lambda=0.08, \mathrm{~F}=3.78, \mathrm{P}=0.002)$ and $\mathrm{P}_{-} \mathrm{PO}_{4}(\lambda=0.05, \mathrm{~F}=2.85, \mathrm{P}=0.002)$ in explaining the variability of ciliates in all habitats. On the RDA triplot the species commonly observed in WKC/R, Astylozoon sp., Codonella cratera and Urotricha sp., and two species of WKC, Askenasia sp. and C. margaritaceum, correspond with the decreasing temperature gradient (Fig. 3A). The ciliates Cyrtohymena muscorum, Paramecium bursaria and Spirostomum ambigum correspond with the WKC habitat and the increasing gradient of $\mathrm{P}_{-} \mathrm{PO}_{4}$. A large group of species inhabiting the littoral and pelagic zones, Amphileptus cleparedei, A. pleurosigma, Chilodonella uncinata, Colpidium colpoda, Spathidium sensu lato and Stentor coeruleus, correspond with the increasing $\mathrm{pH}$ gradient (Fig. $3 \mathrm{~A})$. The results of the RDA for cladocerans showed that all the environmental variables together explained $48.1 \%$ of the total variability. The Monte Carlo permutation test indicated the significance of two variables, visibility $(\lambda=0.04, \mathrm{~F}=2.06, \mathrm{P}=0.044)$ and total suspension $(\lambda=0.09$, $\mathrm{F}=4.71, \mathrm{P}=0.036$ ), in explaining the variability of cladocerans along the habitats studied. On the RDA triplot the abundances of Alonella exigua, Leptodora kindtii, Pleuroxus laevis, Pleuroxus truncatus and Scapholeberis mucronata correspond with the $\mathrm{L}$ and $\mathrm{P}$ habitats and the increasing gradient of total suspension (Fig. 4A). Secchi disc visibility was associated with the presence of three cladocerans, Acroperus elongatus, Pseudochydorus globosus and Simo- cephalus vetulus, inhabiting the WKC and $\mathrm{L}$ habitats. For copepods, the environmental variables explained $70.3 \%$ of their total variance in analysed habitats. Three variables, visibility $(\lambda=0.09, \mathrm{~F}=4.54, \mathrm{P}=0.004)$, temperature $(\lambda=0.11$, $\mathrm{F}=6.38, \mathrm{P}=0.002)$ and $\mathrm{Ptot}(\lambda=0.05, \mathrm{~F}=2.96, \mathrm{P}=0.034)$, showed significant importance in the Monte Carlo permutation test. On the RDA triplot, two species inhabiting the $\mathrm{P}$ habitat, Cyclops bicolor and Paracyclops poppei, correspond with the decreasing gradient of Ptot (Fig. 5A). Temperature was found to significantly determine abundance of Acanthocyclops trajani and A. robustus in the $\mathrm{L}$ and $\mathrm{P}$ habitats. A large group of species (Acanthocyclops einslei, Cyclops strenuus, Cyclops vicinus, Diacyclops bicuspidatus, Eudiaptomus graciloides and Mesocyclops leuckartii) and copepodites of Calanoidae and Cyclopoidae correspond with the rising visibility gradient.

In Ceratophyllum-dominated lakes all the variables together explained $78.2 \%$ of the total variance. Variables that significantly $(\mathrm{P}<0.05$, Monte Carlo permutation test) explained the variance in the abundance of planktonic communities were $\mathrm{pH}(\lambda=0.24 ; \mathrm{F}=14.44 ; \mathrm{P}=0.016)$, dissolved oxygen $(\lambda=0.03 ; \mathrm{F}=3.51 ; \mathrm{P}=0.016)$, conductivity $(\lambda=0.05 ; \mathrm{F}=4.60 ; \mathrm{P}=0.002)$, total suspension $(\lambda=0.07$; $\mathrm{F}=5.55 ; \mathrm{P}=0.006), \mathrm{N}^{-N_{4}}(\lambda=0.06 ; \mathrm{F}=4.94 ; \mathrm{P}=0.010), \mathrm{N}-$ $\mathrm{NO}_{3}(\lambda=0.04 ; \mathrm{F}=3.95 ; \mathrm{P}=0.018)$ and $\mathrm{P}-\mathrm{PO} 4(\lambda=0.13$; $\mathrm{F}=9.54 ; \mathrm{P}=0.002)$. On the RDA triplot, Axis 1 appears to separate components of the planktonic food web, with
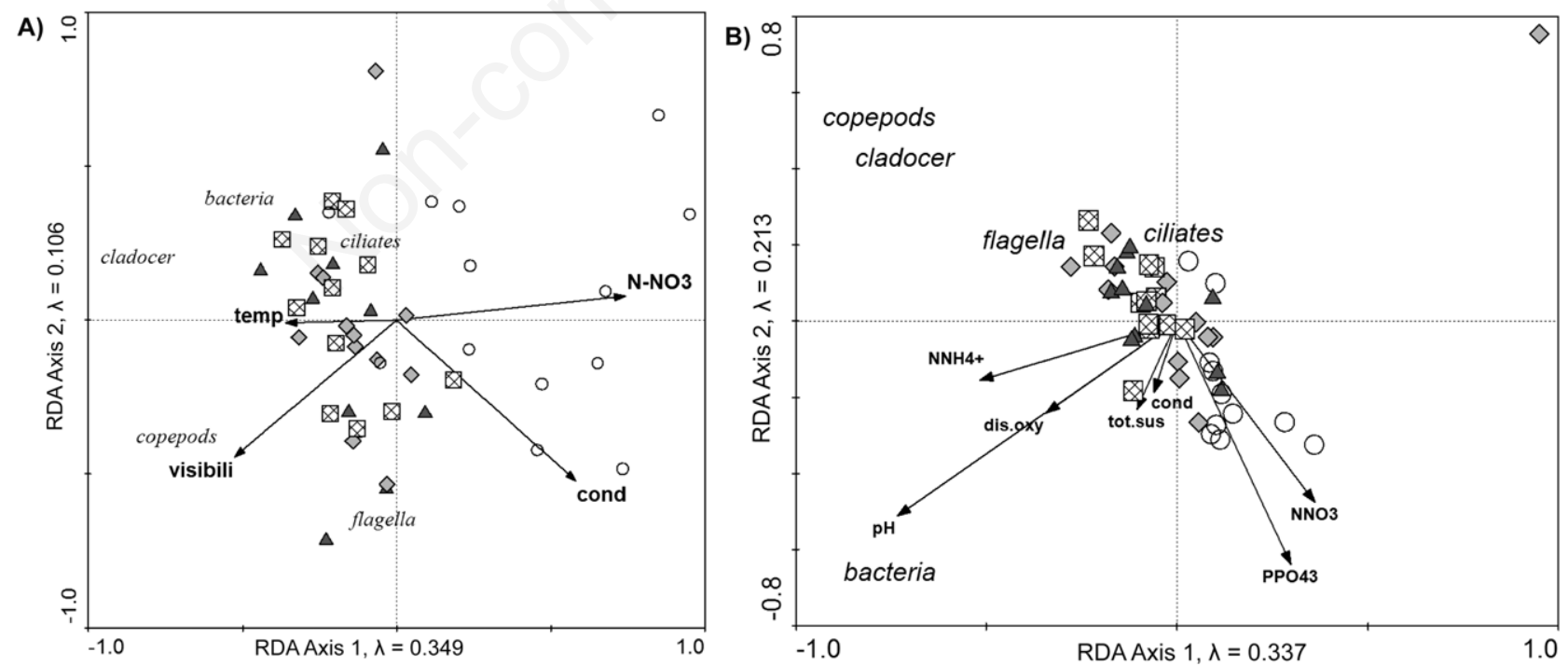

Fig. 2. Triplot of Redundancy Analysis showing components of planktonic food web, studied sites and environmental variables in A) Potamogeton-dominated lakes and B) Ceratophyllum-dominated lakes. Solid black arrows indicate significant variables based on Monte Carlo permutation test $(P<0.05)$. Samples collected at studied sites are marked with geometric figures. White circles, Wieprz-Krzna Canal (WKC); grey diamonds, contact zone: canal/reservoir (WKC/R); crossed squares, littoral zone (L); grey triangles, pelagic zone (P); Chl-a, chlorophyll- $a$; cond, conductivity; dis.oxy, dissolved oxygen; N-NH4, ammonium nitrogen; N-NO3, nitrate nitrogen; Ptot, total phosphorous; P-PO4, dissolved orthophosphates; temp, water temperature; tot.sus, total suspension; visibili, Secchi disc depth; flagella, flagellates; cladocer, cladocera. 
bacteria separated from flagellates, ciliates, cladocerans and copepods (Fig. 2B). Samples collected in WKC/R and the littoral zone correspond with abundances of flagellates and ciliates. However, RDAs performed separately for planktonic groups (ciliates, cladocerans and copepods) revealed substantial differences in relationships between species and environmental parameters. The RDA for spatial distribution of ciliates showed that all the environmental variables together explained $88.3 \%$ of the total variance. The Monte Carlo permutation test showed the significance of visibility $(\lambda=0.05, \mathrm{~F}=2.62, \mathrm{P}=0.010)$, total suspension $(\lambda=0.07, \mathrm{~F}=3.53, \mathrm{P}=0.006)$, dissolved oxygen $(\lambda=0.03, \mathrm{~F}=1.74, \mathrm{P}=0.040)$ and chlorophyll-a $(\lambda=0.03$, $\mathrm{F}=1.57, \mathrm{P}=0.038$ ) in explaining the variability of ciliates in all habitats. On the RDA triplot the species commonly observed in WKC, Paradileptus elephantinus and S. ambigum, correspond with the decreasing gradient of dissolved oxygen (Fig. 3B). The ciliates A. cleparedei, Balanion planctonicum, Strombidium spp., S. viride and Urocentrum turbo correspond with the WKC/R and P habitats and the rising gradient of visibility. A large group of species inhabiting the littoral and pelagic zones, $A s$ pidisca costata, Chlamydonella sp., C. colpoda, Colpoda cucullus, Colpoda steinii, C. uncinata, Euplotes sp., Lacrymaria olor, P. bursaria, S. coeruleus and Vorticella companula, correspond with the decreasing gradient of chlorophyll- $a$ and total suspension (Fig. 3B). The results of the RDA for cladocerans showed that all the environmental variables together explained $46.4 \%$ of the total variability. The Monte Carlo permutation test indicated the significance of five variables, i.e. temperature $(\lambda=0.04$, $\mathrm{F}=1.89, \mathrm{P}=0.048)$, total suspension $(\lambda=0.03, \mathrm{~F}=1.83$, $\mathrm{P}=0.044), \mathrm{N}-\mathrm{NH}_{4}(\lambda=0.03, \mathrm{~F}=1.72, \mathrm{P}=0.037), \mathrm{N}-\mathrm{NO}_{3}$ $(\lambda=0.06, \mathrm{~F}=2.80, \mathrm{P}=0.036)$ and $\mathrm{Ptot}(\lambda=0.06, \mathrm{~F}=3.07$, $\mathrm{P}=0.012$ ), in explaining the variability of cladocerans along the habitats. On the RDA triplot the abundances of Alona affinis and Pleuroxus uncinatus correspond with the WKC habitat and the rising gradient of total phosphorous (Fig. 4B). Temperature corresponds with the presence of Alona costata, Bosmina coregoni, Ceriodaphnia quadrangula, D. cucullata, Diaphanosoma brachyurum, Pleuroxus truncatus and Sida crystallina inhabiting the L and P habitats. The presence of Daphnia longispina corresponds with the increasing gradient of total suspension and the L habitat. N-NH4 may influence the presence of Alona guttata, Alona intermedia, Ceriodaphnia rec-
A)

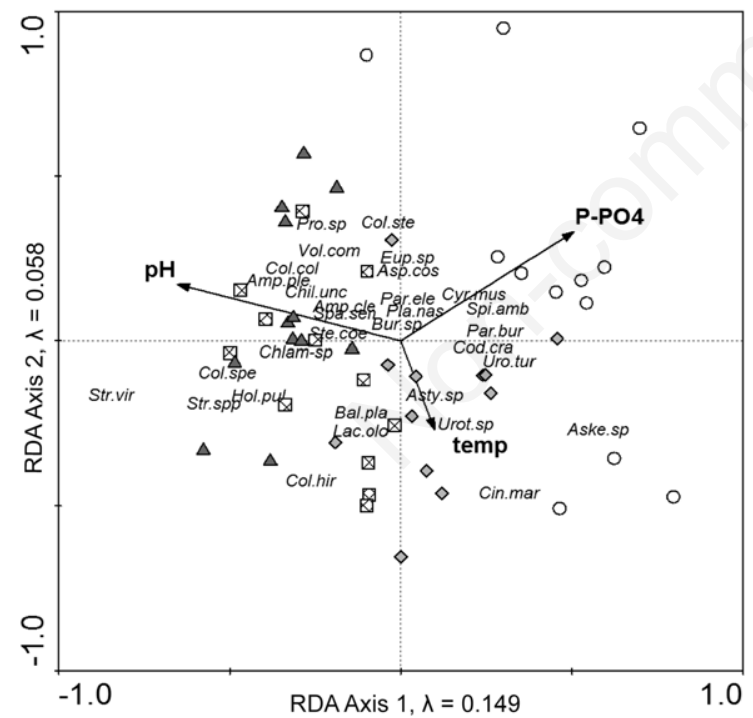

B)

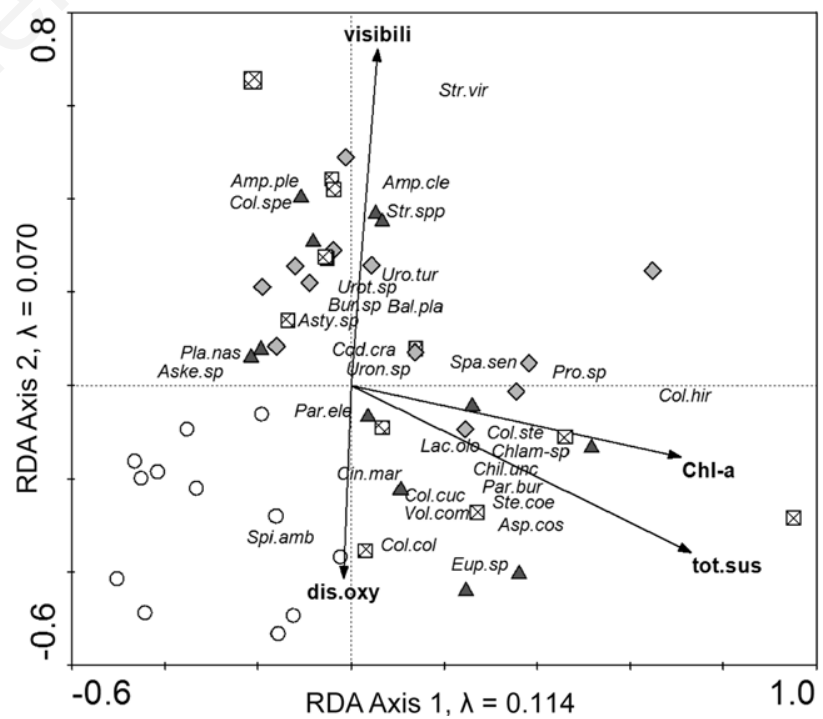

Fig. 3. Redundancy Analysis triplot showing ciliate species, studied sites and significant environmental variables based on Monte Carlo permutation test $(\mathrm{P}<0.05)$ in A) Potamogeton-dominated lakes and B) Ceratophyllum-dominated lakes. Explanations of studied sites and environmental variables are the same as on Fig. 2. Amp.cle, Amphileptus cleparedei; Amp.ple, Amphileptus pleurosigma; Aske.sp, Askenasia sp.; Asp.cos, Aspidisca costata; Asty.sp, Astylozoon sp.; Bal.pla, Balanion planctonicum; Bur.sp, Bursellopsis sp.; Chil.unc, Chilodonella uncinata; Chlam-spr, Chlamydonella-spr; Cin.mar, Cinetochilum margaritaceum; Cod.cra, Codonella crater; Col.hir, Coleps hirtus; Col.spe, Coleps spetai; Col.col, Colpidium colpoda; Col.cuc, Colpoda cucullus; Col.ste, Colpoda steinii; Cyr.mus, Cyrtohymena muscorum; Dre.rev, Drepanomonas revolute; Eup.sp, Euplotes sp.; Hol.pul, Holosticha pullaster; Lac.olo, Lacrymaria olor; Oxy.sp, Oxytricha sp.; Par.ele, Paradileptus elephantinus; Par.bur, Paramecium bursaria; Pla.nas, Plagiopyla nasuta; Pro.sp, Prorodon sp.; Spa.sen, Spathidium sensu lato; Spi.amb, Spirostomum ambigum; Ste.coe, Stentor coeruleus; Strvir, Strombidium viride; Str.spp, Strombilidium spp.; Sty.myt, Stylonychia mytilus-Komplex; Uro.tur, Urocentrum turbo; Uron.sp, Uronema sp.; Urot.sp, Urotricha sp.; Vol.cam, Vorticella campanula. 
tirostris and Pleuroxus laevis, and correspond with the WKC/R habitat.

For copepods, the environmental variables explained $83.3 \%$ of their total variance in the habitats studied. Four variables, visibility $(\lambda=0.10, \mathrm{~F}=6.14, \mathrm{P}=0.004)$, temperature $(\lambda=0.08, \mathrm{~F}=5.61, \mathrm{P}=0.002)$, conductivity $(\lambda=0.04, \mathrm{~F}=3.28$, $\mathrm{P}=0.034)$ and $\mathrm{P}_{-} \mathrm{PO}_{4}(\lambda=0.20, \mathrm{~F}=11.81, \mathrm{P}=0.002)$, showed significant importance in the Monte Carlo permutation test. On the RDA triplot, two species, Eucyclops macruroides and M. leuckartii, inhabiting the $\mathrm{WKC} / \mathrm{R}, \mathrm{L}$ and $\mathrm{P}$ habitats, correspond with the rising temperature gradient (Fig. 5B). A group of species (Cryptocyclops bicolor, Eucyclops graciloides, Eucyclops macruroides and Thermocyclops crassus) and copepodites of Calanoidae and Cyclopoidae correspond with the decreasing visibility gradient and with the littoral and pelagic zones. The presence of the species Eucyclops serrulatus corresponds with the rising conductivity gradient and with the $\mathrm{WKC} / \mathrm{R}$ and $\mathrm{L}$ habitats.

\section{Relationships between planktonic food web components}

Generally, the number of significant correlations between the main groups of the planktonic food web differed between the sites and lake types (Tab. 3). In Potamogetondominated lakes, in WKC flagellates correlated positively with density of ciliates $(\mathrm{r}=0.52, \mathrm{P}=0.028)$ and copepods $(\mathrm{r}=0.61, \mathrm{P}=0.003)$. In WKC/R bacterial density correlated positively with the density of cladocerans $(r=0.54$, $\mathrm{P}=0.037$ ), while flagellates showed a positive correlation with density of ciliates $(\mathrm{r}=0.58, \mathrm{P}=0.035)$ and copepods $(\mathrm{r}=0.67, \mathrm{P}=0.025)$. The number of significant correlations was highest in the littoral zone. The number of bacteria showed a significant positive correlation with ciliates $(\mathrm{r}=0.49, \mathrm{P}=0.032)$, cladocerans $(\mathrm{r}=0.89, \mathrm{P}=0.016)$ and copepods $(\mathrm{r}=0.81, \mathrm{P}=0.041)$ and a negative relationship with the number of flagellates $(\mathrm{r}=-0.78, \mathrm{P}=0.046)$. Flagellates showed a significant negative correlation with the number of cladocerans $(\mathrm{r}=-0.94, \mathrm{P}<0.001)$ and copepods $(\mathrm{r}=-0.93, \mathrm{P}<0.001)$. In the open water zone bacterial density exhibited a negative correlation with the density of copepods $(\mathrm{r}=-0.65, \mathrm{P}=0.026)$, and densities of ciliates and cladocerans were negatively correlated $(\mathrm{r}=-0.85, \mathrm{P}=0.029)$. In Ceratophyllum-dominated lakes, flagellates showed a significant positive correlation with the density of copepods $(\mathrm{r}=0.61, \mathrm{P}=0.033, \mathrm{WKC})$ and ciliates $(\mathrm{r}=0.51$, $\mathrm{P}=0.042$, littoral zone) and negative relationships with bac-
A)

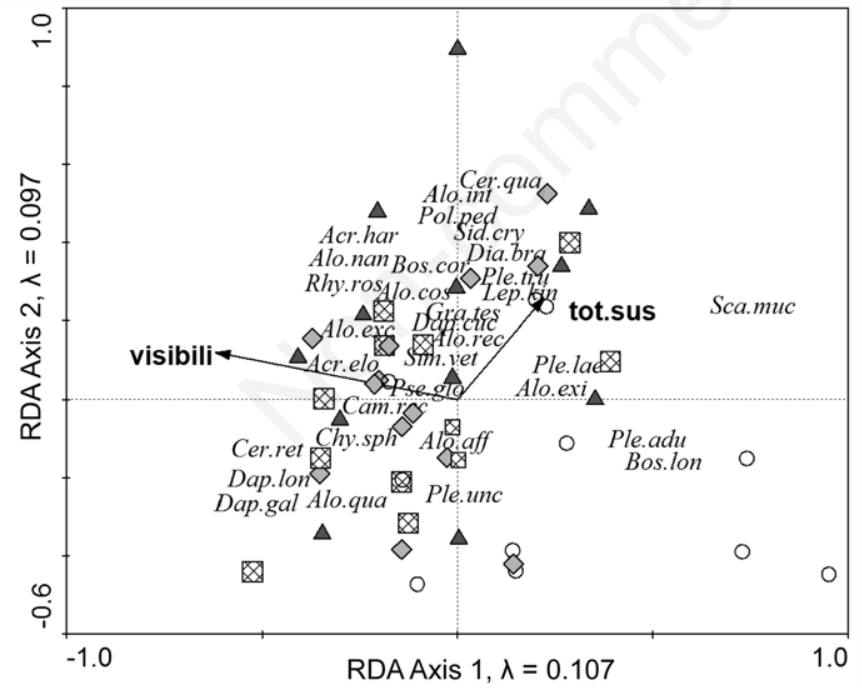

B)

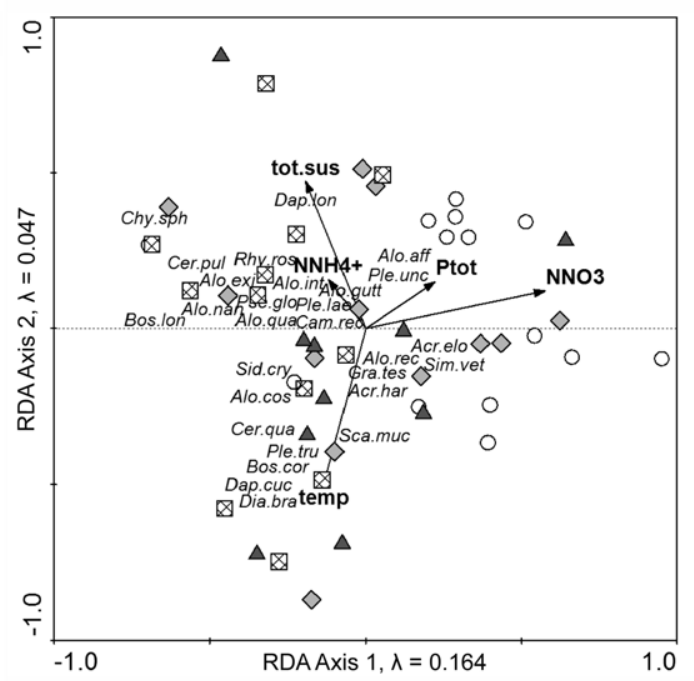

Fig. 4. Redundancy Analysis triplot showing cladocerans species, studied sites and significant environmental variables based on Monte Carlo permutation test $(\mathrm{P}<0.05)$ in A) Potamogeton-dominated lakes and B) Ceratophyllum-dominated lakes. Explanations of studied sites and environmental variables are the same as on Fig. 2. Alo.aff, Alona affinis; Alo.cos, Alona costata; Acr.elo, Acroperus elongates; Anch.ema, Anchistropus emarginatus; Alo.exc, Alonella excise; Alo.exi, Alonella exigua; Alo.gutt, Alona guttata; Acr.har, Acroperus harpae; Alo.int, Alona intermedia; Alo.nan, Alonella nana; Alo.qua, Alona quadrangularis; Alo.rec, Alona rectangular; Bos.cor, Bosmina coregoni; Bos.lon, Bosmina longirostris; Cer.meg, Ceriodaphnia megops; Cer.pul, Ceriodaphnia pulchella; Cer.qua, Ceriodaphnia quadrangular; Cam.rec, Camptocercus rectirostris; Cer.ret, Ceriodaphnia reticulate; Chy.sph, Chydorus sphaericus; Dap.amb, Daphnia ambigua; Dia.bra, Diaphanosoma brachyurum; Dap.cuc, Daphnia cucullata; Dap.gal, Daphnia galeata; Dap.lon, Daphnia longispina; Gra.tes, Graptoleberis testudinaria; Lep.kin, Leptodora kindtii; Ley.ley, Leydygia leydygii; Ple.adu, Pleuroxus aduncus; Pse.glo, Pseudochydorus globosus; Ple.lae, Pleuroxus laevis; Pol.ped, Polyphemus pediculus; Ple.tri, Pleuroxus trigonellus; Ple.tru, Pleuroxus truncates; Ple.unc, Pleuroxus uncinatus; Rhy.ros, Rhynhotalona rostrata; Sid.cry, Sida crystalline; Sca.muc, Scapholeberis mucronata; Sim.vet, Simocephalus vetulus. 
teria $(\mathrm{r}=-0.66, \mathrm{P}=0.020, \mathrm{WKC} / \mathrm{R})$ and copepods $(\mathrm{r}=-0.94$, $\mathrm{P}<0.001$, littoral zone). Bacterial density correlated positively with ciliates $(\mathrm{r}=0.46, \mathrm{P}=0.036$, littoral zone $)$ and cladocerans $(\mathrm{r}=0.81, \mathrm{P}=0.049$, littoral zone and $\mathrm{r}=0.65$, $\mathrm{P}=0.022$, pelagic zone).

\section{DISCUSSION}

\section{Food web vs environmental parameters}

The trophic status of lakes is usually estimated on the basis of several variables (Carlson, 1977). The lakes stud- ied, while displaying insignificant differences in trophic status, varied significantly in other physical and chemical parameters that apparently influenced diversity in the food web components and the mutual relations among them. Potamogeton-dominated lakes displayed lower influence of environmental variables on plankton communities and showed higher densities of bacteria, Cladocera and Copepoda, whereas in the Ceratophyllum-dominated lakes higher influence of environmental variables on plankton communities were found and much lower densities of those communities were observed. In both lake types,
A)

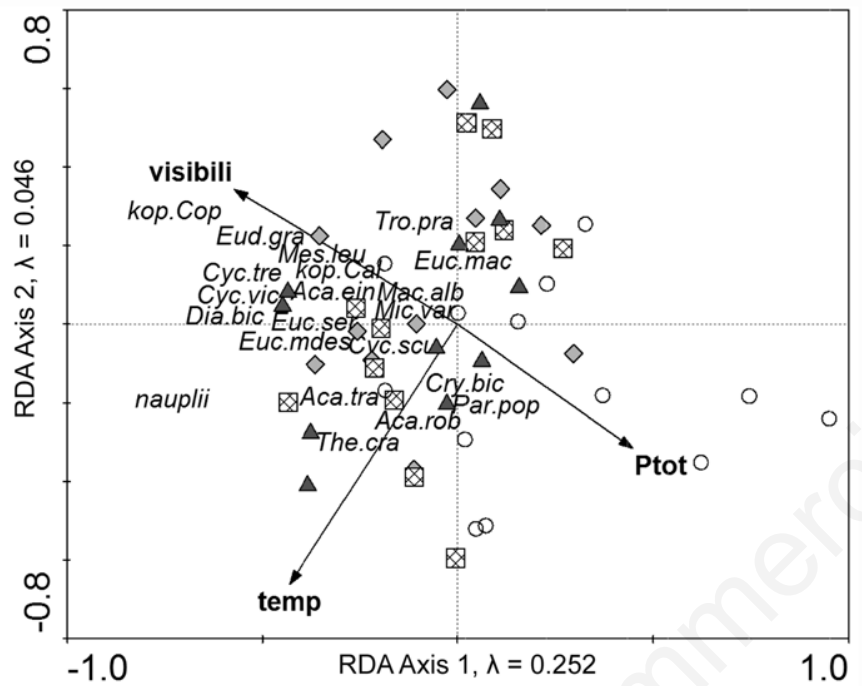

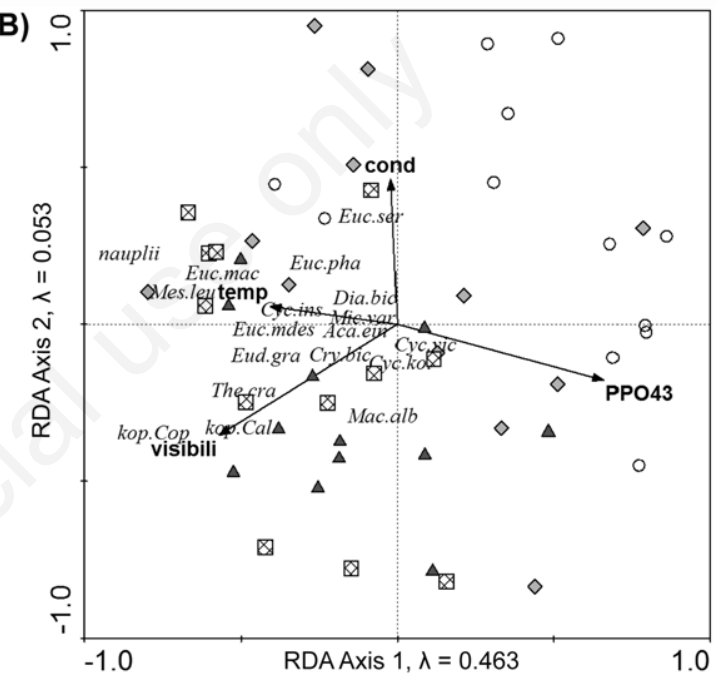

Fig. 5. Redundancy Analysis triplot showing copepods species, studied sites and significant environmental variables based on Monte Carlo permutation test $(\mathrm{P}<0.05)$ in A) Potamogeton-dominated lakes and B) Ceratophyllum-dominated lakes. Explanations of studied sites and environmental variables are the same as on Fig. 2. Aca.ein, Acanthocyclops einslei; Aca.rob, Acanthocyclops robustus; Aca.tra, Acanthocyclops trajani; Cry.bic, Cryptocyclops bicolor; Cyc.ins, Cyclops insignis; Cyc.kol, Cyclops kolensi; Cyc.scu, Cyclops scutifer; Cyc.tre, Cyclops strenuus; Cyc.vic, Cyclops vicinus; Dia.bic, Diacyclops bicuspidatus; Dia.cra, Diacyclops crassicaudis; Eud.gra, Eudiaptomus graciloides; Euc.mdes, Eucyclops macruroides; Euc.mac, Eucyclops macrurus; Euc.ser, Eucyclops serrulatus; Mac.alb, Macrocyclops albidus; Mac.dis, Macrocyclops distinctus; Mes.leu, Mesocyclops leuckartii; Mic.var, Microcyclops varicans; Par.pop, Paracyclops poppei; The.cra, Thermocyclops crassus; Tro.pra, Tropocyclops prasinus; kop.Cal, copepodites Calanoidae; kop.Cop, copepodites Cyclopoidae.

Tab. 3. Values of Spearman correlation coefficients between components of planktonic food web in investigated lakes.

\begin{tabular}{|c|c|c|c|c|c|c|c|c|}
\hline & \multicolumn{4}{|c|}{ Potamogeton-dominated lakes } & \multicolumn{4}{|c|}{ Ceratophyllum-dominated lakes } \\
\hline & WKC & WKC/R & L & $\mathbf{P}$ & WKC & WKC/R & L & $\mathbf{P}$ \\
\hline Bacteria:flagellates & -0.17 & -0.17 & $-0.78^{*}$ & -0.16 & -0.49 & $-0.66 *$ & -0.11 & -0.48 \\
\hline Bacteria:ciliates & -0.39 & -0.34 & $0.49 *$ & 0.37 & -0.14 & -0.14 & $0.46^{*}$ & 0.21 \\
\hline Bactera:cladocerans & -0.20 & $0.54 *$ & $0.89 *$ & 0.08 & -0.23 & 0.03 & $0.81 *$ & $0.65^{*}$ \\
\hline Bacteria:copepods & -0.05 & -0.05 & $0.81^{*}$ & $-0.65^{*}$ & -0.27 & 0.08 & 0.21 & 0.26 \\
\hline Flagellates:ciliates & $0.52 *$ & $0.58^{*}$ & -0.05 & -0.15 & 0.06 & -0.21 & $0.51^{*}$ & 0.34 \\
\hline Flagellates:cladocerans & -0.02 & -0.06 & $-0.94 * *$ & 0.42 & -0.04 & 0.14 & -0.31 & -0.14 \\
\hline Flagellates:copepods & $0.61 *$ & $0.67 *$ & $-0.93 * *$ & 0.24 & $0.61 *$ & -0.03 & $-0.94 * *$ & 0.25 \\
\hline Ciliates:cladocerans & -0.20 & -0.02 & -0.03 & $-0.85^{*}$ & 0.19 & -0.07 & 0.52 & 0.22 \\
\hline Ciliates:copepods & 0.28 & 0.28 & 0.27 & -0.51 & -0.17 & -0.08 & -0.29 & 0.23 \\
\hline
\end{tabular}

WKC, Wieprz-Krzna Canal; WKC/R, contact zone; L, littoral; P, pelagic zone. $* P<0.05$; **P<0.01. 
planktonic communities differed significantly in the horizontal gradient. Most ciliates dominant across the horizontal gradient were eurytopic species which have rapid ecological adaptability and a wide range of tolerance for environmental changes. Along the horizontal gradient bacterivorous ciliates prevailed. This suggests that ciliates in eutrophic ecosystems constitute a significant link in the flow of matter and energy between bacteria and higher invertebrates. The small proportion of algivorous and algaediatom feeder ciliates in the habitats studied may have been caused by problems with food availability. Like ciliates, the cladocerans and copepods occurring in the horizontal gradient were eurytopic species found in lakes despite their trophic status. However, while macroplankton showed much higher abundances in the Potamogetondominated lakes, this group displayed higher species diversity in the Ceratophyllum-dominated lakes. In the former, despite differences in the horizontal distribution of Cladocera and Copepoda, both groups had a stable dominance structure in all sites, with $B$. longirostris as the dominant cladoceran and $T$. crassus as the dominant copepod. $B$. longirostris is a cosmopolitan species that prefers eutrophic conditions and displays wall-to-wall behaviour with even horizontal and vertical distribution (Adamczuk, 2012; Jensen et al., 2013). Similarly, T. crassus is regarded as an environmentally-tolerant species with invasive ability (Duchovnay et al., 1992; Gutiérrez-Aguirre and $\mathrm{Su}, 2000)$. In the Ceratophyllum-dominated lakes, low density of Crustacea coincided with quite high species diversity, which was seen in the dominance structure. Although both $B$. longirostris and $T$. crassus also obtained high densities, they were co-dominated by $D$. cucullata, C. sphaericus, A. nana, M. leuckartii and M. albidus. The significant correlations between microbial communities and copepods suggest that Copepoda may have a key role in transferring energy from the microbial to the classical food web, especially when we consider that their grazing effect occurs at each developmental stage, including larvae, immature and mature individuals (Adamczuk et al., 2015).

The Monte Carlo permutation test showed that the food web components in the Ceratophyllum-dominated lakes were more strongly affected by water chemistry. Environmental variables were less important in the Potamogeton-dominated lakes for abundances of food web components. Interestingly, different trophic relations were observed in the two types of lakes. In the Ceratophyllumdominated lakes, which were more strongly affected by environmental variables, the relationships between food web components were weaker. The influence of predator activity control on lower trophic levels generally decreases with increasing nutrient levels (McQueen et al., 1986, 1989; Brett and Goldman, 1996), but some studies suggest that top-down control is in fact most pronounced in nutrient-rich lakes (Leibold, 1989; Sarnelle, 1992; Jeppesen et al., 1997). However, total suspension (TS) could have an important effect on trophic relations among food web components. This variable was found to be an important factor influencing the spatial distribution of all planktonic communities in the Ceratophyllum-dominated lakes. This variable was probably responsible for both the significant relationships between bacteria and higher trophic levels and the weak relationships between microorganisms and higher trophic levels. Detrital particles constituting mostly TS created a medium for bacterial development. Some studies have reported that more than half of the bacterioplankton in aquatic ecosystems may be attached to detrital particles (Simon 1987; Riemann et al., 2000), and the abundance of those particles influences the density, biomass and production of the attached bacteria (Kepkay, 1994; Carrias et al., 2002). Both ciliates and crustaceans can consume particles, including the attached bacteria (Shimeta 1993; Lemarchand et al. 2006; Suzuki et al., 2014), and detrital particles with attached bacteria can often be more quantitatively important food for zooplankton (Gons et al., 1992). It is generally accepted that cladocerans transfer energy by eating components of microbial food webs and being preyed on by higher components of the classical food chain, including predatory copepods. Many studies attribute a key role in energy transfer in food webs to Daphnia species. However, while $D$. cucullata had a substantial contribution in the dominance structure in the Ceratophyllum-dominated lakes, correlations between microbial food web components and cladocerans were weaker than in the Potamogeton-dominated lakes, where B. longirostris, currently regarded as a minor food web component, was the dominant species. Many reports suggest that $B$. longirostris can have much stronger influence on bacterial communities than Daphnia species (Porter et al. 1983; Vague, Pace 1992). Thus, it is possible that high abundances of bacteria as food source contributed to high densities of B. longirostris in Potamogeton-dominated lakes.

\section{Interactions between food web components - horizontal changes}

Comparative data concerning the distribution of bacteria, protozoa and crustaceans in the horizontal transect (WKC $-\mathrm{WKC} / \mathrm{C}-\mathrm{L}-\mathrm{P}$ ) have thus far been very scarce. Low density of planktonic communities was found in the WKC, probably due to current velocity, which confirms results obtained by Primc-Habdija et al. (1998). A visible increase in the density of microbial communities usually occurred in the canal-reservoir contact zone $\mathrm{WKC} / \mathrm{R}$. Most species found at all stations were eurytopic species, which have rapid ecological adaptability and a broad tolerance range for environmental changes. The ecotone zone is usually inhabited by a large number of species 
(Harris 1988). At particular sites some physical or chemical water properties influenced the quality and quantity structure of planktonic ciliates. The increase in organic matter and nutrient concentrations was correlated with a higher number of taxa and abundance of microorganisms. The presence of emergent vegetation in the ecotone zone may also influence the abundance of zooplankton by slowing the current and the development of microhabitats. Several mechanisms may account for the contact zone and macrophyte beds being a more favourable habitat for zooplankton to develop (Bunn, Artington 2002). Macrophyte beds in eutrophic lakes provide zooplankton with a refuge against invertebrate and vertebrate predators (Jeppesen $e t$ al., 1998; Mieczan, 2007). Cladocerans and copepods, although abundant along the whole horizontal gradient, attained the highest densities in the pelagic zone (P). Their density could be regulated by planktivorous fish, as the contact zone is a place of forage for obligatory planktivorous fish fry, which play an important role in eliminating zooplankton (Whiteside, 1988; Zalewski et al., 1990).

As mentioned above, environmental variables had different effects on density and mutual relations of food web components in the two lake types, which suggest that the stronger effect of environmental variables weakens trophic relationships among food web components. Environmental variables also influenced trophic relationships within individual lakes. Analysis of the system bacteriaflagellates-ciliates-crustaceans reveals a clear differentiation and strength of mutual relations between the zones analysed. The highest number of significant correlations was determined in the canal-reservoir contact zone $\mathrm{WKC} / \mathrm{R}$ and $\mathrm{L}$, and the lowest number in WKC and P. In $\mathrm{WKC} / \mathrm{R}$ and $\mathrm{L}$, more mutual relations between food web components were determined than in the other zones analysed. Jeppesen et al. (1998) suggest that an increased abundance of microorganisms should be effectively reduced by zooplankton inhabiting the macrophyte zone. Our study, however, reveals high numbers of microbial communities in this zone despite a number of correlations between them and higher trophic levels. Foraging efficiency of invertebrate predators decline with increasing complexities of habitats (Adamczuk, 2013); thus the patchy structure of the ecotone zone apparently favoured the coexistence of prey-predator communities. It seems that in the fairly homogenous pelagic zone $(\mathrm{P})$ crustaceans could diminish the abundance of microbial communities, which suggests that the spatial architecture of habitats is an important factor influencing mutual relationships between microbial communities and their predators. It seems also that morphology of macrophytes and range of their occurrence in a lake can have crucial influence on relations among food web components in a whole lake scale. In Ceratophyllum-dominated lakes that displayed wider area grown by macrophytes of more complex mor- phology in comparison to Potamogeton-dominated lakes, weak relations among food web components were noted in all biotic zones. Thus, our results suggest that debilitating influence of complex habitats on relationships among food web components is not only restricted to those habitats but impacts a whole lake area.

\section{CONCLUSIONS}

The present study showed clear horizontal distribution patterns of bacteria, flagellates, ciliates and crustaceans in the horizontal gradient of shallow lakes. The analysis of trophic relationships in the system bacteria-ciliates-crustaceans reveals a clear differentiation and strength of mutual relations between the zones analyzed. The highest number of significant correlations was determined in the littoral zone. It can also be a place of very efficient matter and energy flow in freshwater ecosystem. Environmental variables influenced the density of planktonic communities but did not affect their spatial distribution, which probably resulted from the eurytopic habits of species commonly found in shallow, eutrophic lakes. Environmental variables apparently influenced the strengths of interactions between microbial communities and their predators. In the Ceratophyllum-dominated lakes, where environmental variables explained the bulk of the total variance in plankton abundance, weak relations among food web components were noted, whereas in the Potamogeton-dominated lakes, where environmental variables had a minor role in the total variance in plankton abundance, strong predator-prey relations were found. The spatial structure of habitats proved to be another significant factor for relationships among food web components, as our study revealed that habitat complexity can reduce negative correlations between food web components. Inter- and intra-lake differences in spatial structure are frequently ignored in field studies on functioning of eutrophic lakes. Yet our data suggest that trophic relations in eutrophic lakes are more heterogeneous that they have been considered by now, and variation in diversity and abundance of food components should be considered at small spatial scales. Without doing so, we cannot fully know biotic structure in eutrophic lakes that are often falsely perceived as quite homogenous ecosystems.

\section{REFERENCES}

Adamczuk M, 2012. Spatial distribution of juvenile and adult stages of limnetic Cladocera in relation to selected environmental factors. J. Limnol. 71:112-118.

Adamczuk M, 2013. The effect of habitat complexity on the contribution of some littoral-benthic Cladocera to the pelagic food web. Marine Freshwat. Res. 64:1049-1057.

Adamczuk M, Mieczan T, Nawrot D, Rechulicz J, 2015. Indirect effect of environmental factors on interactions between microbial and classical food webs in freshwater ecosystems. Ann. Limnol.-Internat. J. Limnol. 51:49-58. 
Augustin H, Foissner W, Adam H, 1984. An improved pyridinated silver carbonate method which need few specimens and yields permanent slides of impregnation ciliates (Protozoa, Ciliophora). Mikroskopie 41:134-137.

Azam F, Fenchel T, Field JG, Gray JS, Mayer-Reil LA, Thindstad F, 1983. The ecological role of water-column microbes in the sea. Marine Ecol. 10:257-263.

Biyu S, 2000. Planktonic protozooplankton (ciliates, heliozoans and testaceans) in two shallow mesotrophic lakes in China - a comparative study between a macrophyte-dominated lake (Biandantang) and algal lake (Houhu). Hydrobiologia 434:151-163.

Brett MT, Goldman CR, 1996. A meta-analysis of the freshwater trophic cascade. Proceed. Nat. Acad. Sci. 93:7723-7726.

Bunn SE, Arthington A, 2002. Basic principles and ecological consequences of altered flow regimes for aquatic biodiversity. Environ. Manage. 30:492-507.

Carlson RE, 1977. A trophic state index for lakes. Limnol. Oceanogr. 22:361-369.

Caron DA, 1983. Technique for enumeration of heterotrophic and phototrophic nanoplankton, using epifluorescence microscopy and comparison with other procedures. Appl. Environment. Microbiol. 46:491-498.

Carros JF, Serre JP, Sime-Ngando T, Amblard C, 2002. Distribution, size, and bacterial colonization of pico- and nanodetrital organic particles (DOP) in two lakes of different trophic status. Limnol. Oceanogr. 47:1202-1209.

Dawidek J, Sobolewski S, Turczyński M, 2004. Transformations of catchmet-areas of lakes converted into storage reservoirs in the Wieprz-Krzna Canal system. Limnol. Rev. 4:67-74.

Di Castri F, Hansen AJ, Holland MM, 1988. A new look at ecotones: emerging international projects on landscape boundaries. Biol. Internat. 17:1-163.

Duchovnay A, Reid JW, McIntosh A, 1992. Thermocyclops crassus (Crustacea: Copepoda) present in North America: a new record from Lake Champlain. J. Great Lakes Res. 18:415-419.

Ejsmont-Karabin J, 2003. Is sandy beach of the lake an ecotone? Psammon rotifera in a mesotrophic Lake Kuc (Masurian Lakeland, Northern Poland). Pol. J. Ecol. 51:219-224.

Fermani P, Diovisalvi N, Torremorell A, Lagomarsioni L, Zagarese HE, Unrein F, 2013. The microbial food web structure of a hypertrophic warm-temperate shallow lake, as affected by contrasting zooplankton assemblages. Hydrobiologia 714:115-130.

Fleituch T, Starzecka A, Bednarz T, 2001. Spatial trends in sediment structure, bacteria, and periphyton communities across a freshwater ecotone. Hydrobiologia 464:165-174.

Foissner W, Berger H, 1996. A user-friendly guide to the ciliates (Protozoa, Ciliophora) commonly used by hydrobiologists as bioindicators in rivers, lakes and waste waters, with notes on their ecology. Freshwat. Biol. 35:375-470.

Foissner W, Berger H, Schaumburg J, 1999. Identification and ecology of limnetic plankton ciliates. Informationsberichte des Bayer. Landesamtes für Wasserwirtschaft, München.

Golterman HL, 1969. Methods for chemical analysis of freshwaters. Blackwell Scientific Publications, Oxford, Edinburgh.

Gons HJ, Berger-Wiersma T, Otten JH, Rijkeboer M, 1992. Coupling of phytoplanbkton and detritus in a shallow, eutrophic lake (Lake Loosdrecht, The Netherlands). Hydrobiologia 233:51-59.
Gutiérrez-Aguirre M, Su E, 2000. The Eurasian Thermocyclops crassus (Fischer, 1853) (Copepoda, Cyclopoida) found in southeastern Mexico. Crustaceana 73:705-713.

Harris LD, 1988. Edge effect and conservation of biotic diversity. Conserv. Biol. 2:330-332.

Hillbricht-Ilkowska A, Węgleńska T, 2003. River-lake system as mosaic pattern of landscape patches and their transition zones (ecotones). Pol. J. Ecol. 2:163-174.

Jensen TC, Dimante-Deimantovica I, Schartau AK, Walseng B, 2013. Cladocerans respond to differences in trophic state in deeper nutrient poor lakes from Southern Norway. Hydrobiologia 715:101-112.

Jeppesen E, Jensen JP, Søndergaard M, Lauridsen T, Pedersen LJ, Jensen L, 1997. Top-down control in freshwater lakes: the role of nutrient state, submerged macrophytes and water depth. Hydrobiologia 342/343:151-164.

Jeppesen E, Lauridsen TL, Kairesalo T, Perrow MR, 1998. [Impact of submerged macrophytes on fish-zooplankton interactions in lakes.] In: Jeppesen, E, M. Sondergaard, K. Christofersen (eds.), [The structuring role of submerged macrophytes in lakes]. Springer, New York.

Jeppesen E, Jensen PJ, Sondegaard M, Lauridsen T, Landkildehus F, 2000. Trophic structure, species richness and biodiversity in Danisch lakes: changes along a phosphorus gradient. Freshwat. Biol. 45:201-218.

Jürgens K, Jeppesen E, 1997. Cascading effect on microbial food web structure in a dense macrophyte bed. Ecol. Stud. 131:262-273.

Kairesalo T, Kornijów R, Luokkanen E, 2000. Trophic cascade structuring a plankton community in a strongly vegetated lake littoral. Verh. Int. Verein. Limnol. 26:1846-1851.

Kepkay PE, 1994. Particle aggregation and the biological reactivity of colloids. Marine Ecol. 109: 293-304.

Kuczyńska-Kippen N, 2005. On body size and habitat selection in rotifers in a macrophyte-dominated lake Budzyńskie, Poland. Aquatic Ecol. 39:477-454.

Leibold MA, 1996. A graphical model of keystone predators in food webs: trophic regulation of abundance, incidence, and diversity patterns in communities. Amer. Natur. 147:784-812.

McQueen DJ, Post JR, Mills EL, 1986. Trophic relationships in freshwater pelagic ecosystems. Canad J Fish Aquat. Sci. 43:1571-1581.

McQueen DJ, Johannes MR, Post JR, Stewart TJ, Lean DR, 1989. Bottom-up and top-down impacts on freshwater pelagic community structure. Ecol. Monogr. 59:289-309.

Lemarchand C, Jardillier L, Carrias JF, Richardot M, Debroas D, Sime-Ngando M, Amblard C, 2006. Community composition and activity of prokaryotes associated to detrital particles in two contrasting lake ecosystems. FEMS Microb. Ecol. 57:442-451.

Mieczan T, 2007. Size spectra and abundance of planktonic ciliates within various habitats in a macrophyte - dominated lake (Eastern Poland). Biologia 62:189-194.

Mieczan T, Tarkowska-Kukuryk M, 2013. Diurnal dynamics of the microbial loop in peatlands: structure, function and relationship to environmental parameters. Hydrobiologia 717:189-201.

Pierce RW, Turner JT, 1992. Ecology of planktonic ciliates in marine food webs. Rev. Aquat. Sci. 6:139-181.

Pomeroy LR, 1974. The ocean's food web, a changing paradigm. Bioscience 24:499-504. 
Porter KG, Fleig YS, 1980. The use of DAPI for identifying and counting aquatic microflora. Limnol. Oceanogr. 25:943-948.

Porter KG, Orcutt JD, Gerritsen J, 1983. Functional response and fitness in a generalist filter feeder, Daphnia magna (Cladocera: Crustacea). Ecology 64:735-742.

Primc-Habdija B, Habdija I, Radanovic I, 1998. Seasonal changes in trophic structure of periphytic ciliates in relation to discharge regime. Internat. Verein. Theoret. Ang. Limnol. Verh. 26:1116-1119.

Riemann L, Steward GF, Azam F, 2000. Dynamics of bacterial community composition and activity in a mesocosm diatom bloom. Appl. Environ. Microbiol. 66:578-587.

Sarnelle O, 1992. Nutrient enrichment and grazer effects on phytoplankton in lakes. Ecology 73:551-560.

Schindler DE, Scheuerell MD, 2002. Habitat coupling in lake ecosystems. Oikos 57:25-41. Segovia BT, Pereira DG. Bini LM, de Meira BR, Nishida S, Lansac-Toha FA, Velho LFM, 2015. The role of microorganisms in a planktonic food web of a floodplain lake. Microb. Ecol. 69:225-233.

Shimeta J, 1993. Diffusional encounter of submicrometer particles and small cells by suspension feeders. Limnol. Oceanogr. 38:456-465.

Simon M. 1987. Biomass and production of small and large freeliving and attached bacteria in Lake Constance. Limnol. Oceanogr. 32:591-607.

Suzuki KW, Ueda H, Nakayama K, Tanaka M, 2014. Spatiotem- poral dynamics of stable carbon isotope ratios in two sympatric oligohaline copepods in relation to the estuarine turbidity maximum (Chikugo River, Japan): implications for food sources. J. Plankton Res. 36:461-474.

Ter Braak CJF, 1988-1992. CANOCO-FORTRAN program for Canonical Community Ordination (vers. 2.1). Microcomputer Power, Ithaca.

Whiteside MC, 1988. Fish as major factors affecting abundance patterns of littoral zooplankton. Internat. Verein. Theoret. Ang. Limnol. Verh. 23:1710-1714.

Quinn GP, Keough MJ, 2002. Experimental Design and Data Analysis for Biologists. Cambridge Univ. Press, Cambridge.

Utermöhl H, 1958. Zur vervollkommnung der quantitativen phytoplankton methodik. Internat. Verein. Theoret. Ang. Limnol. Verh. 9:1-38.

Vagué D, Pace ML, 1992. Grazing on bacteria by flagellates and cladocerans in lakes of contrasting food web structure. J. Plankton. Res. 14:307-321.

Xu J, Xie P, Zhang M, Yang H, 2005. Variation in stable isotope signatures of seston and a zooplanktivorous fish in a eutrophic Chinese lake. Hydrobiologia 541:215-220.

Zalewski M, Brewińska-Zaraz B, Frankiewicz P, 1990. Fry communities as a biomanipulation tool in a temperate lowland reservoir. Archiv für Hydrobiol.-Beih. Ergebn Limnol 33:763-774. 